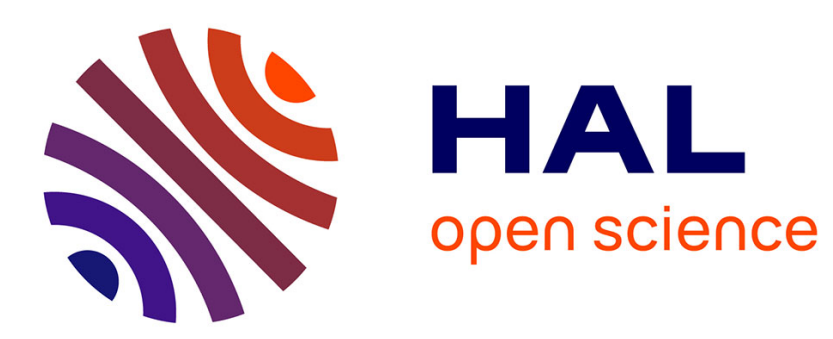

\title{
Subphthalocyanine basicity: reversible protonation at the azomethine bridge
}

\author{
Yann Bernhard, Vivian Lioret, Richard A Decréau
}

\section{To cite this version:}

Yann Bernhard, Vivian Lioret, Richard A Decréau. Subphthalocyanine basicity: reversible protonation at the azomethine bridge. New Journal of Chemistry, 2017, 42 (3), pp.1622-1625. 10.1039/C7NJ02957H . hal-03263289

\section{HAL Id: hal-03263289 \\ https://hal.science/hal-03263289}

Submitted on 17 Jun 2021

HAL is a multi-disciplinary open access archive for the deposit and dissemination of scientific research documents, whether they are published or not. The documents may come from teaching and research institutions in France or abroad, or from public or private research centers.
L'archive ouverte pluridisciplinaire HAL, est destinée au dépôt et à la diffusion de documents scientifiques de niveau recherche, publiés ou non, émanant des établissements d'enseignement et de recherche français ou étrangers, des laboratoires publics ou privés. 

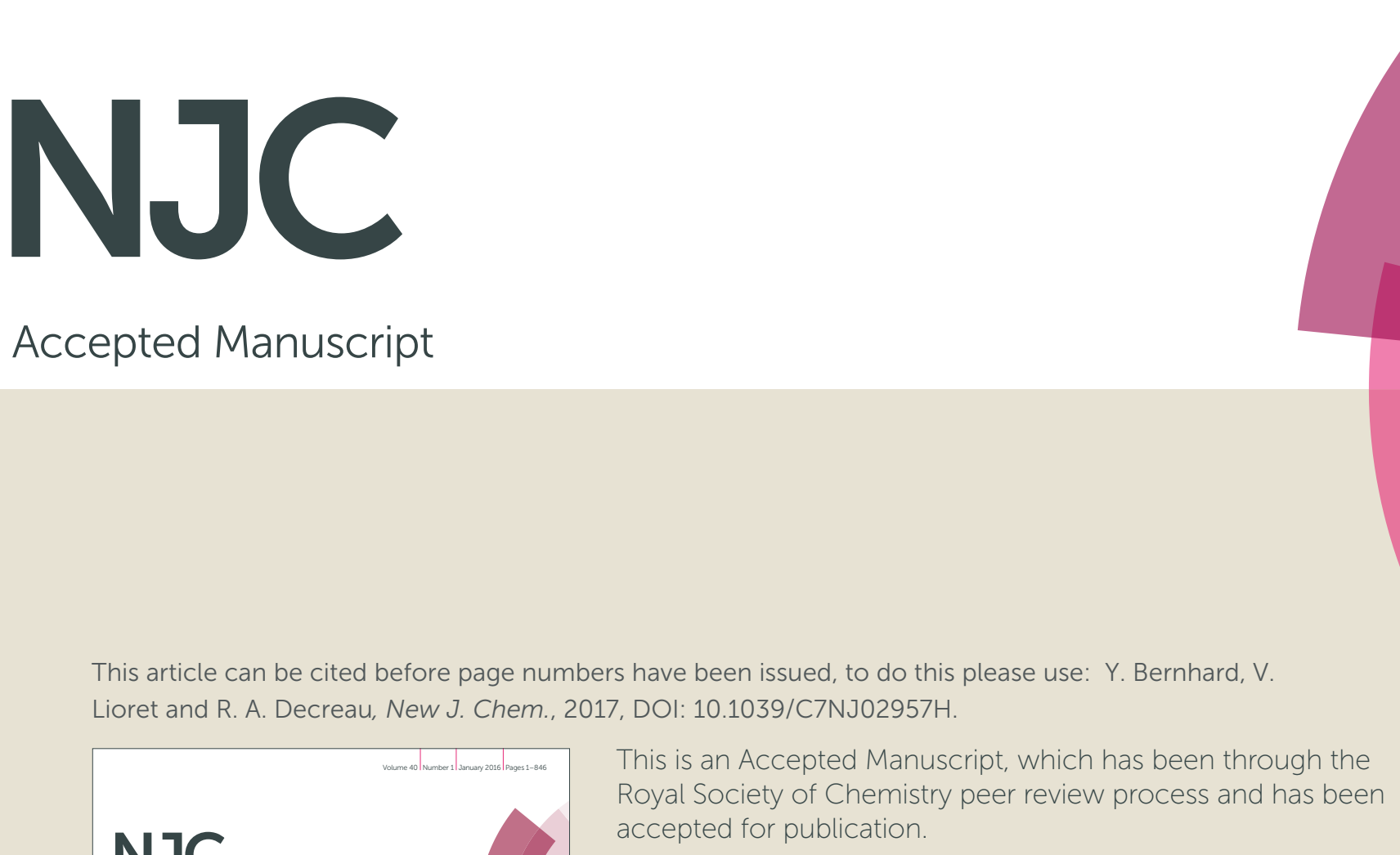

\section{Accepted Manuscript}

This article can be cited before page numbers have been issued, to do this please use: Y. Bernhard, V. Lioret and R. A. Decreau, New J. Chem., 2017, DOI: 10.1039/C7NJ02957H.

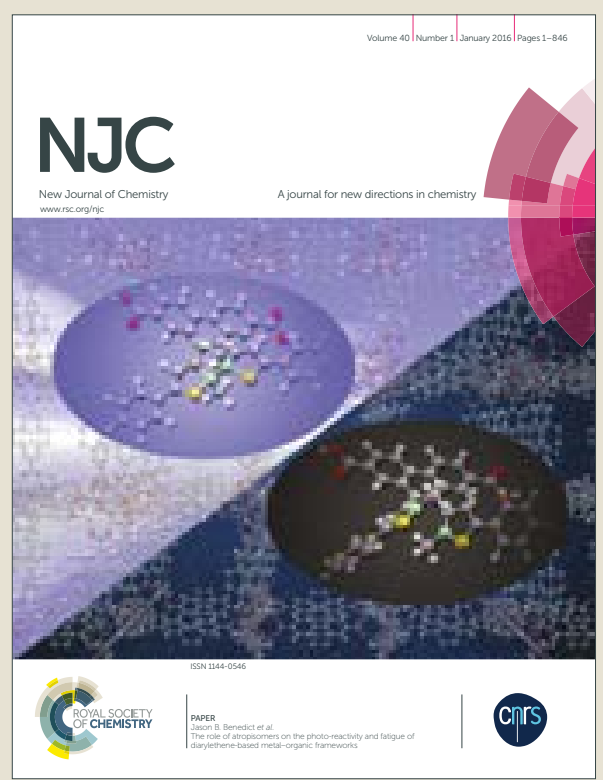

This is an Accepted Manuscript, which has been through the Royal Society of Chemistry peer review process and has been accepted for publication.

Accepted Manuscripts are published online shortly after acceptance, before technical editing, formatting and proof reading. Using this free service, authors can make their results available to the community, in citable form, before we publish the edited article. We will replace this Accepted Manuscript with the edited and formatted Advance Article as soon as it is available.

You can find more information about Accepted Manuscripts in the author guidelines.

Please note that technical editing may introduce minor changes to the text and/or graphics, which may alter content. The journal's standard Terms \& Conditions and the ethical guidelines, outlined in our author and reviewer resource centre, still apply. In no event shall the Royal Society of Chemistry be held responsible for any errors or omissions in this Accepted Manuscript or any consequences arising from the use of any information it contains. 
Received 00th January 20xx, Accepted 00th January 20xx

DOI: $10.1039 / x 0 x \times 00000 x$

\section{Subphthalocyanine basicity: reversible protonation at the azomethine bridge.}

\author{
Yann Bernhard, ${ }^{a}$ Vivian Lioret ${ }^{\mathrm{a}}$ and Richard A. Decréau ${ }^{\mathrm{a}}$
}

www.rsc.org/

\begin{abstract}
Subphthalocyanine (SubPc) could be reversibly protonated at the azomethine bridge. This phenomenon was examined by adressing the pKa of the acid (TFA, MSA, TMSA) and the SubPc electron-withdrawing properties of the peripheral isoindolic substituents $\left(\mathrm{F}_{12}\right.$ vs $\mathrm{H}_{12}$ and $\left.\mathrm{NO}_{2}\right)$, which tunes the basic character of the azomethine moiety. The protonation of up to three azomethines was suggested and monitored spectrophotometrically: appearance of new absorbtion bands at $610,630 \mathrm{~nm}$ and $660 \mathrm{~nm}$, together with marked colour change from purple to blue to green. Evidence of such a protonation was also shown by significant changes in the ${ }^{1} \mathrm{H}-\mathrm{NMR}$ spectrum and new bands in the infrared spectrum .
\end{abstract}

Introduction. Subphthalocyanines (SubPc) are tris-isoindole analogues of phthalocyanines. ${ }^{1}$ They are used as synthons in the synthesis of $A 3 B$ phthalocyanines, and also in various photonic processes, such as photovoltaics, ${ }^{2}$ and optical imaging. ${ }^{3}$ The chemistry of this domed structure has been explored obviously on the ring opening chemistry front, ${ }^{4}$ but also on the apical substitution at the Boron atom. ${ }^{5}$ Reaction with an acid is also of interest: it may drastically affect both the reactivity and the optical properties of the macrocycle. Reactivity with Lewis acids was examined for the apical substitution reaction: ${ }^{6}$ in the presence of aluminium trichloride, a reaction with SubPc takes place leading to a blue coloration that is interpreted as the interaction of $\mathrm{AlCl}_{3}$ with bridging nitrogen atoms (acide-base interaction). Reactivity with Brönsted acid was also mentioned, through the possibiliy to achieve the protonation of azomethine bridges of subphtalocyanines with $\mathrm{H}_{2} \mathrm{SO}_{4} \cdot{ }^{1 \mathrm{~b}}$ Prior reports on the protonation of porphyrins and phthalocyanines has also been reported. For example, mixing phthalocyanines in sulfuric acid or TFA leads to the formation of brown species, that may be

\footnotetext{
a. Institut de Chimie Moléculaire de l'Université de Bourgogne (ICMUB), UMR 6302 CNRS-University of Burgundy Franche Comté, BP 47870, F-21078, Dijon Cedex, France; E-mail : Richard.Decreau@u-bourgogne.fr
}

† Footnotes relating to the title and/or authors should appear here.

Electronic Supplementary Information (ESI) available: [details of any supplementary information available should be included here]. See DOI: $10.1039 / x 0 x x 00000 x$ interpreted as the protonation of one or several azobridges. $^{\text {7ad }}$ As we were working on the protonation of subphthalocyanines (the actual study) a careful study came up addressing the basicity of azomethine in phthalocyanines depending upon the nature of the substituents at the 4,5 or 3,6 positions. ${ }^{7 c d}$ Herein, we report a detailed study on the reaction of SubPc with Brönsted acids: the reversible protonation of $\mathrm{H}_{12} / \mathrm{F}_{12}$ subphthalocyanines was examined with a series of acids the pKa of which range from ca. -15 to 0 (table 1). Hence, such a study explored the possibility to achieve the protonation of up to three azomethine bridges (Fig 1). ${ }^{4}$ Protonations were examined by UV/Vis, ${ }^{1} \mathrm{H}-\mathrm{NMR}$ and infrared spectroscopies.

Equation (1) $\mathrm{R}_{12} \mathrm{SubPc}+\mathrm{nH}^{+} \rightarrow\left[\mathrm{R}_{12} \mathrm{SubPc}-(\mathrm{H})_{\mathrm{n}}\right]^{\mathrm{n}+}(\mathrm{n}=1-3)$

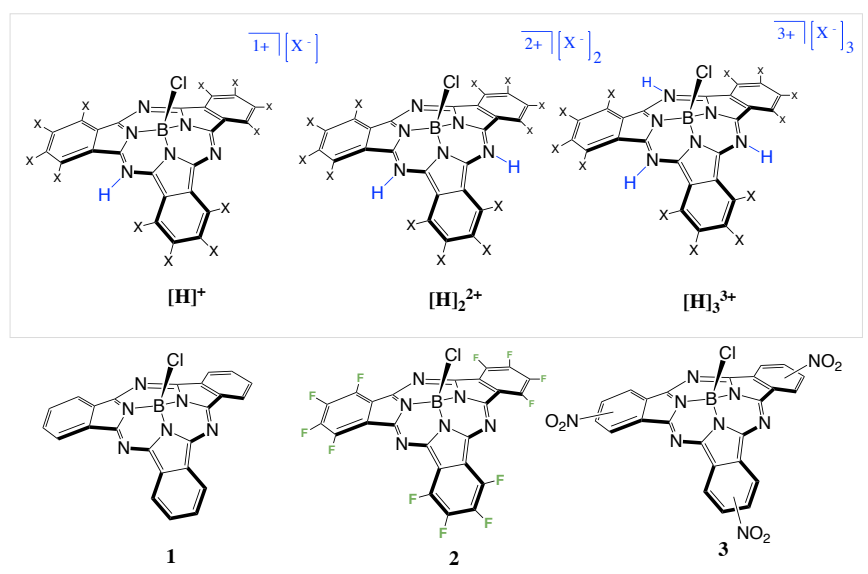

Fig. 1 Top: examples of protonation states in subphthalocyanines. Bottom: protonation of aza-bridges in $X_{12}$-Subphthalocyanine $(X=H, F)$, i.e. subphthalocyanine 1, hexadodecafluorophthalocyanine 2, or tris-nitrosubphthalocyanine 3. $^{3}$ The synthesis of species 1-3 was reported previously. ${ }^{3 a-c}$

UV-Vis. Organic acids as opposed to inorganic acids were used to achieve the synthesis of protonated subphthalocyanine in order to prevent the presence of water presumably responsible for the 
instability of such protonated species. Herein protonation studies were carried out using trifluoroacetic acid (TFA, pKa $=0.3$ ), methanesulfonic acid (MSA, pKa $=-1.9$ ) and trifluoromethanesulfonic acid (TMSA, pKa $=-14.9)$. $\mathrm{A}$ spectrophotometric titration was achieved by monitoring the absorbance upon addition of acid, hence allowing to demonstrate the first protonation step. Upon addition of TFA to a solution of $\mathrm{H}_{12} \mathrm{SubPc} 1$ an absorption band lying at $610 \mathrm{~nm}$ shows up, while the main band decays at the same time, while an isobestic point was observed. Judging from the evolution of the band, it seems that TFA is not strong enough to complete the protonation of the SubPc (Figure 2 (top), Table 1). The absorbance of protonated 1 decreases very slowly over time (Figure 2 (bottom)). The decay is small after $2 \mathrm{~h}(\mathrm{ca}<10 \%)$, and is about $40-50 \%$ after $8 \mathrm{~h}$.
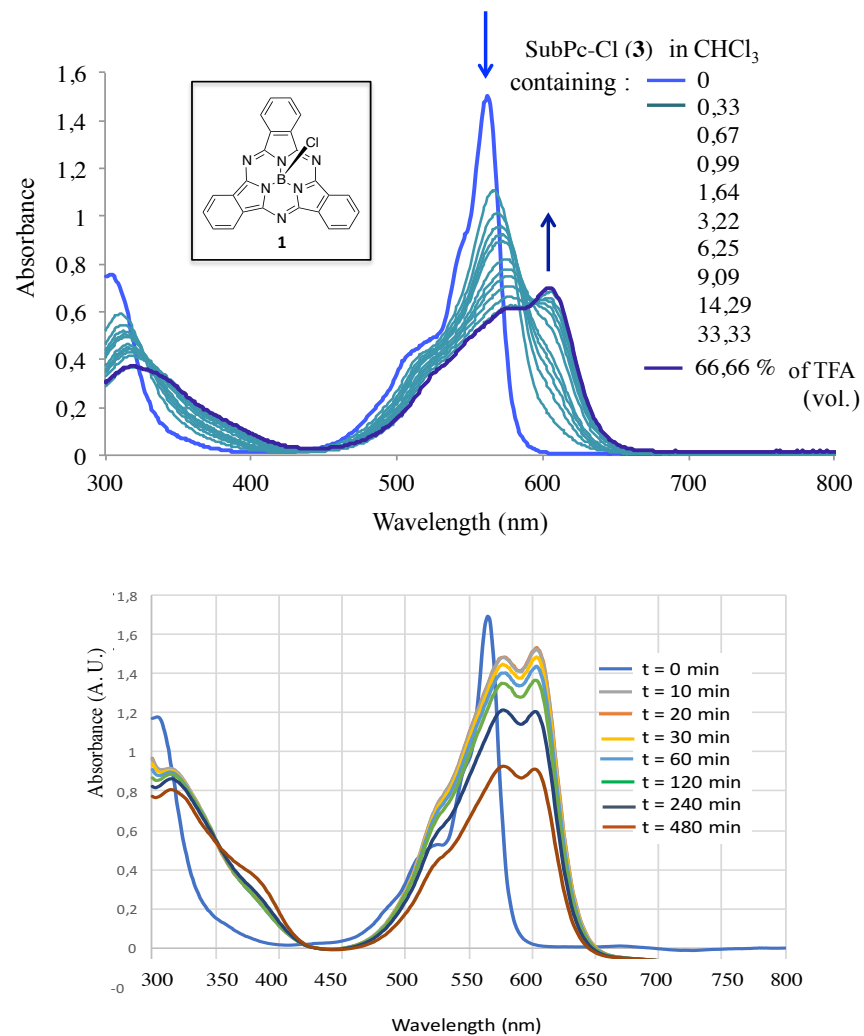

Fig. 2 Titration with TFA. Top. Overlapping of absorption spectra of 1 in chloroform with increasing amounts of TFA. Bottom. Monitoring the absorbance of protonated $\mathbf{1}$ over time (decay becomes substantial after $2 \mathrm{~h}$ ).

\begin{tabular}{|l|l|l|l|l|}
\hline & pKa & $\mathrm{H}_{12}$-SubPc 1 & $\mathrm{F}_{12}$-SubPc 2 & $\begin{array}{l}\text { Estimated } \\
\text { number of } \\
\text { protonated } \\
\text { azomethynes } \\
\mathrm{H}_{12} / \mathrm{F}_{12}\end{array}$ \\
\hline $\mathrm{CHCl}_{3}$ & & 567 & 575 & $0 / 0$ \\
\hline TFA & 0.3 & 610 & 575 & $1 / 0$ \\
\hline MSA & -1.9 & 631 & 629 & $2 / 2$ \\
\hline TMSA & -14.9 & 665 & 674 & $3 / 3$ \\
\hline
\end{tabular}

Table $1 . \mathrm{H}_{12}$ vs $\mathrm{F}_{12}$ Subphthalocyanine absorption bands upon protonation with acids of decreasing pKa values.
When subphthalocyanine 1 was in the presence of a a stronger acid, such as TMSA or MSA, new absorption'1bantis applpeared, together with color changes from pink to purple, blue, and green, respectively. When SubPc 1 was in solution in MSA (pKa $=-1.9$ ) its absorption spectrum shows the appearance of an absorption band at $631 \mathrm{~nm}$ (Fig 3A, pale blue line). When 1 was in solution in TMSA (pKa -14.9) the maximum absorption band that could be detected lies at $665 \mathrm{~nm}$ (Fig 3A, green line). When SubPc was in solution in a dichloromethane/TMSA mixture (1:1 vol.) as opposed to pure TMSA, the compound precipitates, which may be an indication that the formed compound is a multi-charged species (i.e. protonated at several azomethine bridges). The same set of studies was carried out with electro-deficient subphthalocyanine $\mathbf{2}$ that bears 12 electron-withdrawing fluorine atoms. When 2 was in solution in strong acids, such as MSA and TMSA (Figure 3B), absorption bands at $665 \mathrm{~nm}$ (blue line) and $674 \mathrm{~nm}$ (green line) appeared, which is reminiscent of the results with $\mathrm{H}_{12^{-}}$ SubPc 1. However, when 2 was in less acidic TFA ( $p K a=0.3$ ) protonation does not seem to occur as no shift in the absorption band was noticed (Fig. 3B, pink line, table 1), i.e. the UV/Vis shift corresponding to a mono-protonated species is almost not observed). This set of UV/Vis titrations seems to indicate that the titration of the azomethine bridges is a function of the electron density of the macrocycle.

Reversibility. Upon addition of water or a non nucleophilic base to a solution of the protonated subphthalocyanine, subsequent disappearance of the absorption bands of the protonated species occurs, whereas that of the starting subphthalocyanine is usually restored. Hence, such a protonation process occurring at the azomethine bridges appears to be reversible. However, species protonated with MSA and TMSA appear to be less stable during the deprotonation step.

A

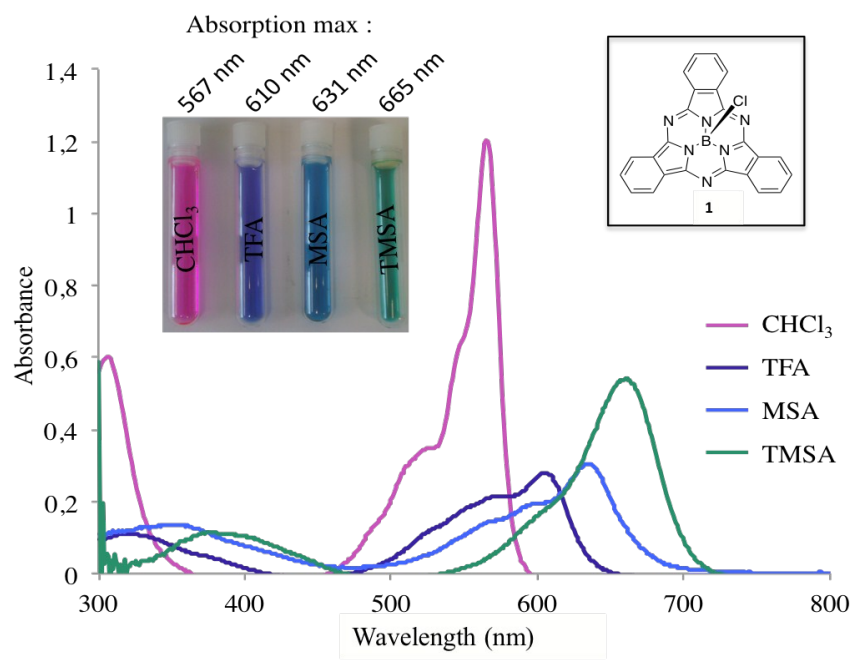


B

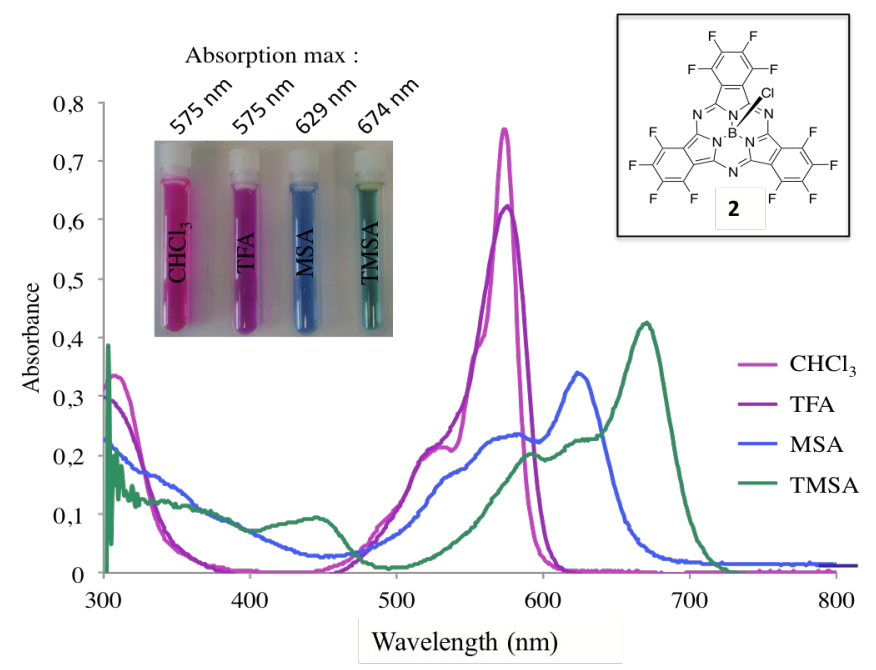

Fig. 3. $U V / V i s$ of $H_{12} \quad\left(A\right.$, top) $/ F_{12} \quad(B$, bottom) Subphthalocyanines 1,2 in solution in chloroform (pink), TFA (dark blue (top) or purple (bottom)), MSA (pale blue), and TMSA (green). Insert: color of a solution of the respective endproducts of compounds $\mathbf{1}$ and $\mathbf{2}$ in solution in chloroform, TFA, MSA, and TMSA).

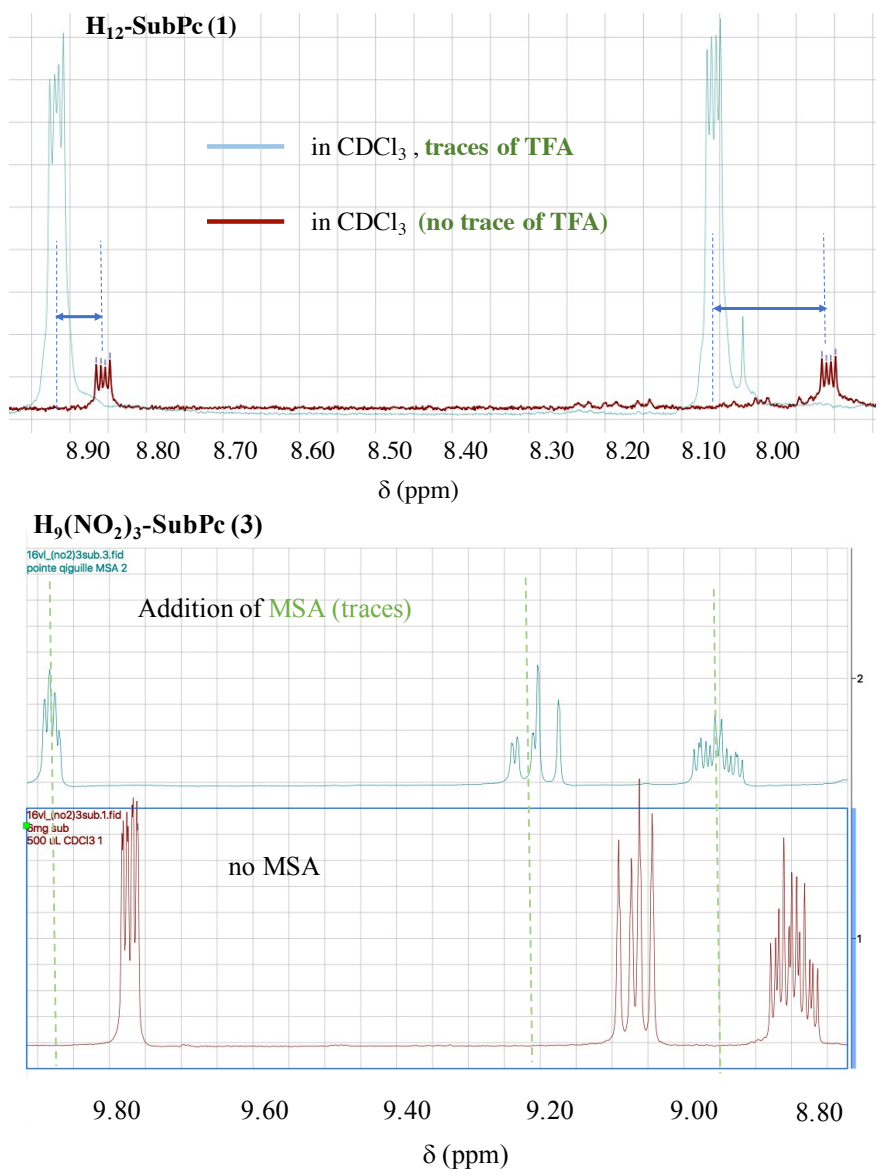

Fig. $4{ }^{1} \mathrm{H}-\mathrm{NMR}$ spectra of protonated SubPc $\mathbf{3}_{\mathrm{V}}\left(\mathrm{t}_{\mathrm{top}}\right)_{\mathrm{ic}}$ abdin $\mathbf{1}$ (bottom).

DOI: $10.1039 / C 7 N J 02957 H$

${ }^{1}$ H-NMR. Upon careful addition of trace amount of MSA, groups of peaks in the ${ }^{1} \mathrm{H}-\mathrm{NMR}$ spectrum of $\mathrm{H}_{9}-\left(\mathrm{NO}_{2}\right)_{3}-$ subphthalocyanine $\mathbf{3}$ are downfield shifted. When more acid was added the perturbation was more pronounced leading to a widespread series of peaks within the window of interest (no precipitation occurred). Hence, it suggests protonation at the subphthalocyanine azomethine bridge. The same trend was confirmed with $\mathrm{H}_{12}$-subphthalocyanine 1 . However, a ${ }^{1} \mathrm{H}-\mathrm{NMR}$ peak corresponding to an iminium-like protonated azomethine bridge $\left(\mathrm{C}={ }^{+} \mathrm{N}-\mathrm{H}\right)$ could not be identified. Also, the spectrum measured in deuterated TFA showed changes in SubPc protons chemical shifts suggesting deuteration of the azomethine bridges.

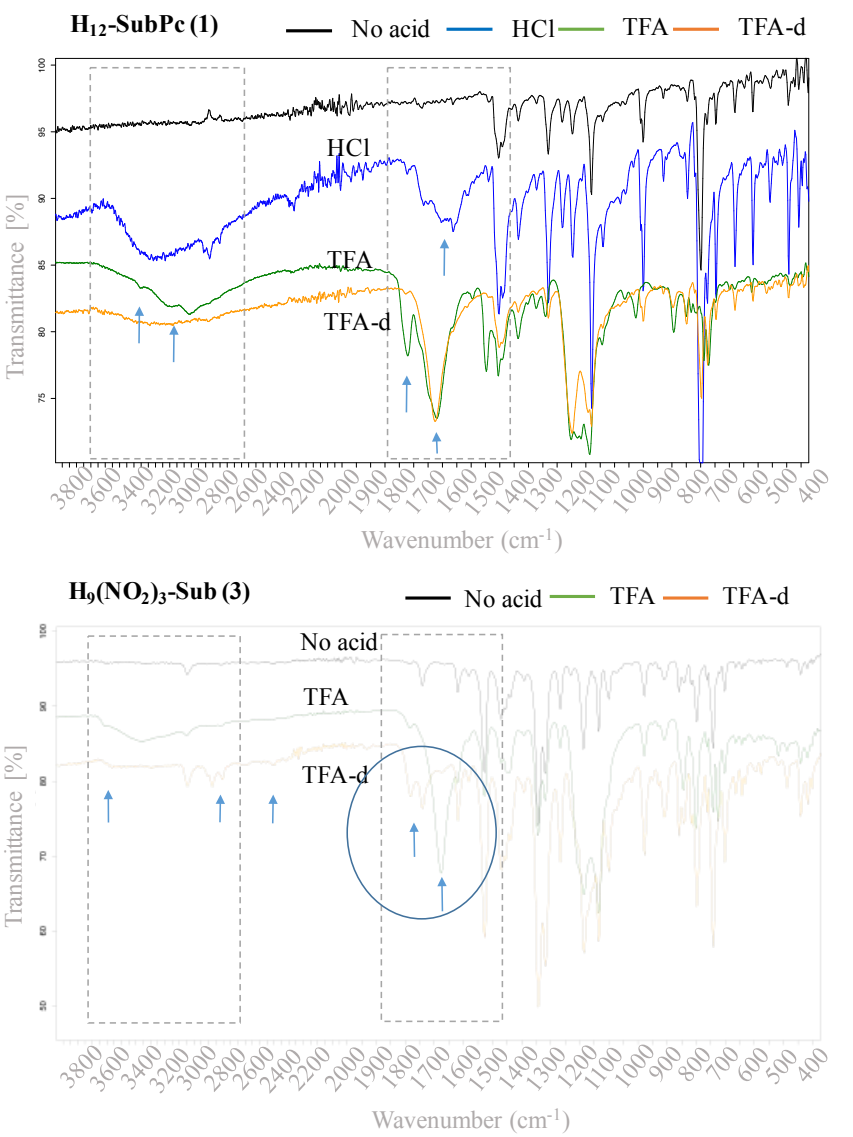

Fig. 5 Infrared spectra of protonated / non protonated SubPc.

\begin{tabular}{|c|c|c|c|}
\hline & DBU & $\mathrm{H}_{12}$-Sub (1) & $\left(\mathrm{NO}_{2}\right)_{3}-\mathrm{Sub}(3)$ \\
\hline \multirow[t]{2}{*}{$\mathrm{HCl}$} & $x$ & 1655,1688 & $x$ \\
\hline & $\mathrm{x}$ & 3278 & $x$ \\
\hline \multirow[t]{2}{*}{ TFA-H } & 1643,1686 & 1671,1772 & 1674 \\
\hline & $x$ & $\begin{array}{c}3406,3209 \\
3060\end{array}$ & $x$ \\
\hline TFA-d & $x$ & 1671,1772 & $x$ \\
\hline
\end{tabular}


Table 2 Infrared bands $\left(\mathrm{cm}^{-1}\right)$ addressing a protonation state in subphthalocyanines.

Infrared. Protonation and deuteration of the azomethine bridge was examined on $\mathrm{H}_{12} \mathrm{SubPc}(\mathbf{1}), \mathrm{H}_{9} \mathrm{SubPc}\left(\left(\mathrm{NO}_{2}\right)_{3}\right)(3)$ and diazabicycloundecene ( $\mathrm{DBU}$, as a possible control, although protonation at the tertiary amine is expected first) (Figure 5, Table 2) upon thorough comparison with the non-protonated parent species. Based on UV/Vis studies it is expected to lead to several protonation states. Upon addition of acid three sets of new bands appeared: A) A broad signal centered at 3278 $\mathrm{cm}^{-1}$ was found when $\mathrm{HCl}$ gas or TFA were added. Three distinct features could be seen when TFA was added, such as $3406 \mathrm{~cm}^{-1}, 3209 \mathrm{~cm}^{-1}$, and $3060 \mathrm{~cm}^{-1}$, some of which may correspond to an $\mathrm{N}-\mathrm{H}$ stretching frequency in an iminium species. When deuterated TFA was used, a band that may correspond to an iminium $={ }^{+} \mathrm{N}-\mathrm{D}$ stretching frequency was found at $2400 \mathrm{~cm}^{-1}$. Deuteration to afford N-D with lower stretching frequencies is in accordance with $\mathrm{N}-\mathrm{H} / \mathrm{D}$ stretching shifts found in the literature. ${ }^{8}$ B) Protonation of an imine results in an increase in the $\mathrm{C}=\mathrm{N}$ frequency. ${ }^{8}$ First, the $\mathrm{C}=\mathrm{N}$ stretching frequency (in a non-protonated / non-quaternized species) is typically found in the $1620-1680 \mathrm{~cm}^{-1}$ window, and appeared to be $1620 \mathrm{~cm}^{-1}$ in the case of subphthalocyanines 1 and 2. When $\mathrm{HCl}$ gas was added to $\mathrm{H}_{12}$-SubPc (1) a band at $1657 \mathrm{~cm}^{-1}$ appeared. When trifluoroacetic acid (TFA) was added, patterns possibly reminiscent of the trifluoroacetate ion were found, ${ }^{9}$ with bands at $1671 \mathrm{~cm}^{-1}$ and $1772 \mathrm{~cm}^{-1}$ $\left(\mathrm{H}_{12} \mathrm{SubPc}(1)\right), 1674 \mathrm{~cm}^{-1}\left(\mathrm{H}_{9}\left(\mathrm{NO}_{2}\right)_{3} \mathrm{SubPc}(3)\right)$ and $1686 \mathrm{~cm}^{-1}$ and $1643 \mathrm{~cm}^{-1}$ (DBU), respectively. When deuterated species was added, the band at $1671 \mathrm{~cm}^{-1}$ no longer appeared, bands around $1800 \mathrm{~cm}^{-1}$ and $2400 \mathrm{~cm}^{-1}$ appeared instead. Moreover, protonation also resulted in both shifting bands and leading to the apparition of new bands.

In summary, this set of experiments all combined provide a strong indication about the protonation of the subphthalocyanines azomethine bridges. Subphthalocyanines are usually quite stable in acidic conditions, provided the acid source is organic with no significant amount of water. Preliminary spectrophotometric titrations show the apparition of three new absorption bands, which may concur with the protonation of up to three azomethine bridges available in the SubPc moieties. Protonation of SubPc (at the azomethine bridge) was also evidenced by significant changes in the ${ }^{1} \mathrm{H}$ NMR spectrum and new bands that appeared in the infrared spectrum addressing ( $\mathrm{N}-\mathrm{H}$ stretch) and other that were affected ( $\mathrm{C}=\mathrm{N}$ stretch). However, mass spectrometry analyses of a solution of SubPc $\mathbf{1}$ in solution in TFA did not show a $M+1$ / $\mathrm{M}+2$ peak indicative of a mono-protonation / monodeuteration processes, or more protonation/deuteration states ( $z>1$, when MSA was used). Overall such results on subphthalocyanine are relevant to other azomethinecontaining species, such as phthalocyanines, salen, rhodopsin. Thorough titration studies are ongoing to determine the equilibrium constant in various peripherally viesubstityted subphthalocyanines addressing variousOlelederonfic Nopasity (such as $\mathbf{1}$ and $\mathbf{2}$ ).

\begin{abstract}
Acknowledgments
Burgundy General Council CRB (FABER program: RD; PhD fellowship: YB), and CNRS (Chaire d'Excellence Program: RD) are acknowledged. Welience ${ }^{\circledR}$ for HR-MS. The Fondation de Coopération Scientifique Bourgogne Franche-Comté.
\end{abstract}

\section{REFERENCES}

1 a) C. G. Claessens, D. Gonzalez-Rodriguez, T. Torres, Chem. Rev. 2002, 102, 835-853; b) C. G. Claessens, D. GonzalezRodriguez, M. S. Rodriguez-Morgade, A. Medina, T. Torres, Chem. Rev. 2014, 114, 2192-2277.

2 Photovoltaic: a) J. Endres, I. Pelczer, B. P. Rand, et al. Chem. Mater. 2016, 28, 794-801; b) Jin, Fangming; Su, Zisheng; Chu, Bei; et al. Scientific Report, 2016, 6, 26262.

3 a) Y. Bernhard, P. Winckler, R. Chassagnon, E. Gigot, J.-M. Perrier-Cornet, R. A. Decréau, Chem. Commun. 2014, 50, 13975-13978; b) Y. Bernhard, P. Winckler, J.-M. PerrierCornet, R. A. Decréau, Dalton Trans., 2015, 44, 3200-3208; c) Y. Bernhard, E. Gigot, V. Goncalves, M. Moreau, N. Sok, P. Richard, R. A. Decreau, Organic Biomol. Chem., 2016, 14, 4511-4518.

4 C. Bonnier, T. P. Bender, Molecules, 2015, 20, 18237-18245.

5 a) N Shibata, B. Das, E. Tokunaga, M. Shiro, N. Kobayashi, Chem. Eur. J. , 16, 7554-7562; b) V. R. Ferro, J.M.G. De La Vega, C.G. Claessens, et al. J. Porphyrins Phthalocyanines, 2001, 5, 491-499.

6 G. E. Morse, T. P. Bender, Inorg. Chem. 2012, 51, 6460-6467.

7 a) T. Honda, T. Kojima, S. Fukuzumi, Chem. Commun. 2011, 47, 7986. b) L. Clougherty, J. Sousa, G. Wyman, J. Org. Chem., 1957, 22, 462-462 ; c) A. Cidlina, J. Svec, L. Ludvova, J. Kunes, P. Zimcik, V. Novakova, J. Porphyrin Phthalocyanines, 2016, 20, $1122-1133$; d) A. Cidlina, M. Miletin, M. Fathi-Rasekh, V. N. Nemykin, P. Zimcik, V. Novakova Chem. Eur. J , 2017, 23, 1795-1804.

8 a) Y. Wang, R. A. Poirier, J. Phys. Chem. A 1997, 101, 907912; b) J. J. Lopez-Garriga, S. Hanton, G. T. Babcock, J. F. Harrison, J. Am. Chem. Soc. 1986, 108, 7251; c) D. Le Pennec, D. Commereuc, Y. Chauvin, IFP, Patent, EP19800401164 $19800807,03 / 11 / 1981$; d) W. J. Westerhaus, O. Knop, Can. J. Chem., 1980, 58, 1355-1364. 


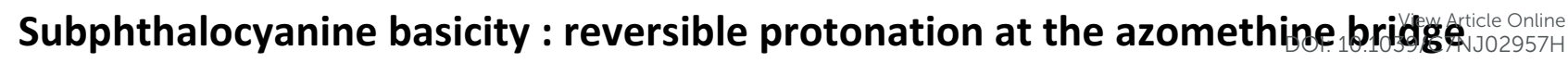

Yann Bernhard, Vivian Lioret, and Richard A Decréau

University of Burgundy Franche Comté

Protonation of subphthalocyanines azomethine bridges is reversible and was evidenced by UV/Vis, $1 \mathrm{H}-\mathrm{NMR}$ and IR.
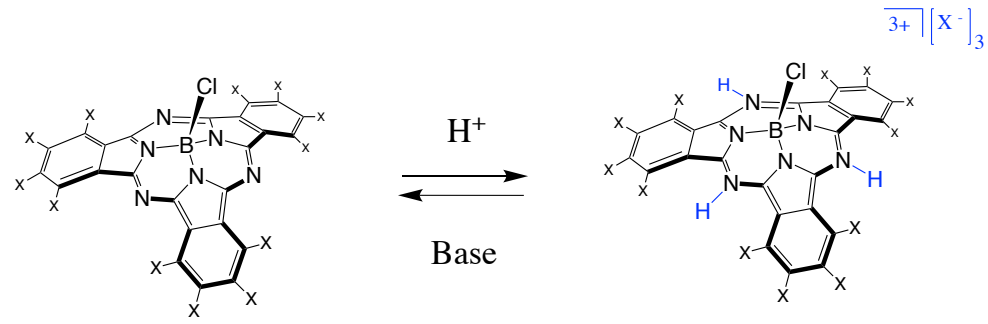